УДК 159.97:159.922.8

\title{
ОСОБЕННОСТИ Я-КОНЦЕПЦИИ ДЕВОЧЕК ПОДРОСТКОВ С НЕСУИЦИДААЬНЫМ САМОПОВРЕЖДАЮЩИМ ПОВЕДЕНИЕМ
}

\author{
С.В. Горбатов, Е.Н. Арбузова, А.В. Шаболтас, В.В. Горбачева \\ ФГБОУ ВО “Санкт-Петербургский государственный университет», г. Санкт-Петербург, Россия
}

\begin{abstract}
FEATURES OF SELF-CONCEPT OF FEMALE ADOLESCENTS WITH NON-SUICIDAL SELF-HARMING BEHAVIOR
\end{abstract}

\author{
S.V. Gorbatov, E.N. Arbuzova, \\ A.V. Shaboltas, V.V. Gorbacheva
}

Saint Petersburg state University, Saint Petersburg, Russia

\begin{abstract}
Информация об авторах:
Горбатов Сергей Владимирович - кандидат психологических наук (SPIN-код: 7522-9225; Researcher ID: N6533-2015; ORCID iD: 0000-0003-3842-9956). Место работы и должность: доцент кафедры психологии здоровья и откАоняющегося поведения ФГБОУ ВО “Санкт-Петербургский государственный университет". Адрес: Россия, 199034, г. Санкт-Петербург, Университетская наб., 7/9. Телефон: +7 (8812) 324-25-74, электронный адрес: s.gorbatov@bk.ru

Арбузова Елена Николаевна - кандидат психологических наук (SPIN-код: 9840-7646; Researcher ID: AAA9352-2020; ORCID iD: 0000-0002-1643-0529). Место работы и должность: доцент кафедры психологии здоровья и откАоняющегося поведения ФГБОУ ВО “Санкт-Петербургский государственный университет". Адрес: Россия, 199034, г. Санкт-Петербург, Университетская наб., 7/9. Телефон: +7 (8812) 324-25-74, эмектронный адрес: asmaen@yandex.ru

Шаболтас А^^а Вадимовна - доктор психологических наук (SPIN-код: 3659-6209; Researcher ID: H-70162013; ORCID iD: 0000-0002-1966-6924). Место работы и должность: декан факультета психологии, заведующая кафедрой психомогии здоровья и отклоняющегося поведения ФГБОУ ВО “Санкт-Петербургский государственный университет». Адрес: Россия, 199034, г. Санкт-Петербург, Университетская наб., 7/9. Темефон: +7 (8812) 324-2574, эмектронный адрес: a.shaboltas@spbu.ru

Горбачева Валерия Викторовна (SPIN-код: 8792-4351; Researcher ID: AAA-9379-2020; ORCID iD: 0000-00019146-0798). Место работы и должность: эксперт-психолог отдемения психофизиологической диагностики филиала "Военно-врачебная комиссия 1" ФКУЗ “Медико-санитарная часть 78 Федеральной службы исполнения наказаний". Адрес: Россия, 199034, г. Санкт-Петербург, наб. реки Фонтанки, д. 36, митер А. Телефон: +7 (8812) 719-89-81, эмектронный адрес: lerunchikk.27@mail.ru
\end{abstract}

Information about the authors:

Gorbatov Sergey Vladimirovich - PhD (SPIN-code: 7522-9225; Researcher ID: N-6533-2015; ORCID iD: 00000003-3842-9956). Place of work and position: Associate Professor of the Department of psychology of health and deviant behavior of St. Petersburg state University. Address: Russia, 199034, Saint Petersburg, 7/9 Universitetskaya nab. Phone: +7 (8812) 324-25-74, email: s.gorbatov@bk.ru

Arbuzova Elena Nikolaevna - PhD (SPIN-code: 9840-7646; Researcher ID: AAA-9352-2020; ORCID iD: 00000002-1643-0529). Place of work and position: associate Professor of the Department of psychology of health and deviant behavior of St. Petersburg state University. Address: Russia, 199034, Saint Petersburg, 7/9 Universitetskaya nab. Phone: +7 (8812) 324-25-74, email: asmaen@yandex.ru

Shaboltas Alla Vadimovna - DSc in Psychology (SPIN-code: 3659-6209; Researcher ID: H-7016-2013; ORCID iD: 0000-0002-1966-6924). Place of work and position: Dean of the faculty of psychology, head of the Department of psychology of health and deviant behavior of St. Petersburg state University. Address: Russia, 199034, Saint Petersburg, $7 / 9$ Universitetskaya nab. Phone: +7 (8812) 324-25-74, email: a.shaboltas@spbu.ru

Gorbacheva Valeria Viktorovna (SPIN-code: 8792-4351; Researcher ID: AAA-9379-2020; ORCID iD: 0000-00019146-0798). Place of work and position: Expert psychologist of the Department of psychophysiological diagnostics of the branch "Military medical Commission 1" of the Federal penitentiary Institution "Medical and sanitary unit 78 of the Federal penitentiary service". Address: Russia, 191014, Saint Petersburg, 36, letter A, nab. Fontanka river. Phone: +7 (8812) 719-89-81, email: lerunchikk.27@mail.ru

Несуицидальное самоповреждение получило значительное распространение среди молодёжи во многих развитых странах мира, в связи с чем, представляет собой серьёзную медико-социальную проблему, требующую всестороннего исследования с целью разработки эффективных мер помощи и профилактики. Цель исследования: изучение особенностей и детерминант самоповреждающего поведения девочек - подростков на основе анализа различных элементов Я-концепции. Характеристики выборки и методы. Обследовано 76 дево- 
чек в возрасте от 15 до 17 лет, из них 37 человек с различными проявлениями саморазрушающего поведения (основная группа), и 39 - здоровые (контрольная группа). В качестве саморазрушающего рассматривались такие формы поведения, которые проявлялись в самоповреждении или нанесении себе физического ущерба при отсутствии осознанных суицидальных намерений. С целью выделения значимых различий между группами проведён уровневый анализ ряда основных психологических характеристик. Статистическая обработка данных проводилась с использованием пакета программ SPSS-21. Результаты. Было установлено, что в структуре черт личности подростков с самоповреждающим поведением наибольший удельный вес составляют факторы, связанные с Я-концепцией. В частности, у них в большей мере выражены показатели самообвинения (83,68 в основной группе и 47,18 в контрольной), неудовлетворённости телом (7,83 и 6,08), эгоцентризма (24,22 и 12,05). Меньше выражено самоотношение $(24,84$ и 78,35), самоуважение $(19,27$ и 70,9$)$ и аутосимпатия $(33,35$ и 61,54), при одновременном повышении общего уровня дезадаптации $(1,68$ и 1,08$)$. По результатам исследования был сделан вывод, что Я-концепция подростков, характеризующихся несуицидальным самоповреждающим поведением, является дисфункциональной. Она не выполняет функций, способствующих психологической адаптации и социальной интеграции подростка, что может, в общем может рассматриваться как фактор повышения суицидального риска.

Ключевые слова: самоповреждающее поведение, суицид, Я-концепция, подросток

Саморазрушающее поведение, в частности такая его форма как несуицидальное самоповреждение (англ. non-suicidalself-injury, NSSI) получило достаточно широкое распространение среди подростков и молодёжи во многих экономически развитых странах мира [1]. Согласно данным отдельных зарубежных исследований его частота может достигать от 13 до 28\% [2, 3]. При этом отмечается, что женщины совершают несуицидальные самоповреждения чаще, чем мужчины [3].

Получение точных данных о распространённости данного вида саморазрушения в России затруднено, так как в отличие от наиболее радикальных форм аутодеструктивного поведения какими, например, является суицид и суицидальные попытки, сопровождающиеся фатальным или тяжёлыми последствиями для здоровья, акты самоповреждения значительно реже попадают в поле зрения медицинских служб или правоохранительных органов. Согласно отдельным отечественным публикациям можно лишь примерно оценить объём проблемы. Например, среди 604 опрошенных школьников 7-11 классов указали на личный опыт самоповреждающих действий 16,9\%. Практически каждый второй (46\%) совершал их неоднократно [4]. Часто самоповреждения ассоциируются с другими формами девиантного поведения [5].

Не меньшее беспокойство среди специалистов вызывает и скорость распространения данного отклонения, прежде всего обусловленная вовлечённостью части подростков и людей молодого возраста в дискурсивные интернет сообщества, в которых активно обсуждаются различные виды самоповреждения, способы нанесения себе ран, а также часто публикуются фотографии нанесённых повреждений $[6,7]$.

Для терапии, профилактики и превенции саморазрушающего поведения, определённое значение имеет понимание различия между эпизодами несуицидального самоповреждающего поведения (НССП) и суицидальной попыткой. В 2013 году НССП было включено
Self-destructive behavior, in particular such a form as non-suicidal self-injury (NSSI), has become quite widespread among adolescents and young people in many economically developed countries of the world [1]. According to the data of some foreign studies, its frequency can reach from 13 to $28 \%[2,3]$. It is noted that women commit non-suicidal selfinjury more often than men [3].

Obtaining accurate data on the prevalence of this type of self-destruction in Russia is difficult, because unlike most radical forms of self-destructive behavior such as, for example, suicide and suicidal attempts, accompanied by fatal or severe consequences for health, acts of self-harm are much less likely to attract attention of medical services or law enforcement. According to individual domestic publications, one can only roughly estimate the prevalence of the problem. For example, among 604 students surveyed in 7-11 grades, $16.9 \%$ indicated personal experience of self-harming actions. Almost every second (46\%) committed them repeatedly [4]. Self-injury is often associated with other forms of deviant behavior [5].

The speed with which this deviation spreads is of no less concern among specialists. It is primarily due to the involvement of some adolescents and young people in discursive online communities, which actively discuss various types of self-injury, how to inflict wounds on oneself, and often post photos of self-harm $[6,7]$.

For the treatment, prevention, and prevention of self-destructive behavior, understanding the difference between episodes of non-suicidal self-injury (NSSI) and suicidal attempt is of some importance. In 2013, the NSSI was included in the Diagnostic and Sta- 
в Международную классификацию расстройств и нарушений (DSM-5) NSSI как отдельное клиническое явление в качестве расстройства, требующего дальнейшего изучения и понимания. Многие исследователи обнаруживают различия между несуицидальным и суицидальным поведением по характеру и частоте действий, различной распространённости в связи с гендерными и возрастными характеристиками начала аутоагрессивных действий, мотивам, прежде всего по тому, что в несуицидальном варианте у человека нет намерения умереть $[8,9,10,11]$. Тем не менее, в силу субъективности, характер намерения крайне сложно верифицировать. Исследования показывают, что намерение умереть - это неустойчивое когнитивное состояние, которое демонстрирует большую временную изменчивость и частые изменения тяжести [12]. Также есть исследования, позволяющие говорить о том, что несуицидальное самоповреждение связано с повышенным риском самоубийства [13]. Так, по мнению J.J. Muehlenkamp и соавт. [14] НССП является надёжным предиктором суицидального поведения. Примерно от 55 до 85\% людей, которые участвуют в несуицидальном самоповреждении, имеют в анамнезе, по крайней мере, одну суицидальную попытку и повышенный суицидальный риск [15]. Некоторые исследователи полагают, что до 70\% людей с историей НССП с высокой долей вероятности предпримут суицидальную попытку в будущем $[16,17]$.

Существование высокой степени совпадения между суицидальными идеями, попытками самоубийства и несуицидальным самоповреждением [18], обнаружение ряда сходств в факторах риска и коррелятах суицидальных попыток и несуицидальном самоповреждении [19], позволяет предполагать, что данные виды аутоагрессии можно рассматривать в общем континууме самоповреждающего поведения, которое может варьировать от «косвенного» самоповреждения (например, нерегулярное употребление алкоголя), «среднего» самоповреждения (например, нанесение себе синяков или ожогов), «тяжёлого» самоповреждения (например, нанесение порезов) до летального самоповреждения [20]. Близка к данному конструкту модель, предлагаемая Ю.В. Поповым [21], рассматривающим саморазрушающее поведение подростков как континуум различных типов саморазрушения, распределённых по тяжести последствий и угрозы для жизни и здоровья. Речь, прежде всего, идёт о суицидальном поведении, начиная от действий, представляющих угрозу для жизни, до поступков, наносящих ущерб будущему социальному статусу индивида. В модели Ю.В. Попова (1991) данный континуум является одной из осей диагностического пространства, в котором двумя другими являются: уровень расстройства (от предпатологии до tistical Manual of mental disorders (DSM-5) as a clinical phenomenon that requires further study and understanding. Many researchers find differences between non-suicidal and suicidal behavior in the nature and frequency of actions, various prevalence in regards to gender and age characteristics of the onset of auto-aggressive actions, motives, and primarily because in a non-suicidal version the person has no intention to die $[8,9,10,11]$. However, due to subjectivity, the nature of intent is extremely difficult to verify. Studies show that intention to die is an unstable cognitive state that demonstrates great temporal variability and frequent changes in severity [12]. There is also research to suggest that non-suicidal selfinjury is associated with an increased risk of suicide [13]. So, according to J.J. Muehlenkamp et al. [14] NSSI is a reliable predictor of suicidal behavior. Approximately 55 to $85 \%$ of people who are engaged into non-suicidal self-injury have a history of at least one suicidal attempt and increased suicidal risk [15]. Some researchers believe that up to $70 \%$ of people with a history of NSSI are more likely to make a suicidal attempt in the future [16, 17].

The existence of a high degree of coincidence between suicidal ideations, suicide attempts and non-suicidal self-injury [18], the discovery of a number of similarities in risk factors and correlates of suicidal attempts and non-suicidal self- injury [19] suggest that these types of auto-aggression can be considered in the general continuum of self-harming behavior, which can vary from "indirect" self-harm (for example, irregular alcohol consumption), "medium" self-harm (for example, bruising and burns), "severe" self-harm (for example, cutting) before fatal self-injury [20]. The model proposed by Yu.V. Popov [21] is close to this design as he considers the self-destructive behavior of adolescents as a continuum of various types of self-destruction, distributed according to the severity of consequences and threat to life and health. First of all, it is related to suicidal behaviors starting from actions that pose a threat to life and ending to the actions that damage the future social of an individual. In the model of Yu.V. Popov (1991), this continuum is one of the axes of the diagnostic spectrum, and the other two are: the level of disorder (from prepathology to psychotic conditions) and the degree of social adaptation (from sustainable to maladaptation).

Thus, it is obvious that studying differ- 
психотических состояний) и степень социальной адаптации (от устойчивой до дезадаптации).

Таким образом представляется, что поиск различий только между клиническими группами разного вида и разной степени тяжести самоповреждений, внутри одного и того же континуума, оказывается явно недостаточным. Исследования показывают, что значительная часть лиц с несуицидальным самоповреждением не демонстрирует клинически значимые уровни психической дисфункции и вопрос о том, что из себя представляет несуицидальное самоповреждение как отклоняющееся и качественно отличающееся от нормы, остаётся открытым [17]. Не меньшее значение имеет в этом смысле вопрос о специфике подросткового возраста. Не являются ли характерные для данного возраста особенности психического функционирования сами по себе благоприятной почвой для формирования аутодеструктивных проявлений, или они в бо̀льшей степени обусловлены сочетанием специфики личностных свойств и стрессогенностью переживаемого индивидом периода жизни. Так, многие исследователи относят НССП к неадаптивной стратегии совладания, используемой людьми, характеризующимися эмоциональной дисрегуляцией, и борющимися с различными эмоциональными трудностями. Такого рода подростки сообщают, что участвуют в несуицидальном самоповреждении, в первую очередь, для уменьшения невыносимых негативных эмоциональных или когнитивных состояний, для самонаказания или для создания хотя бы какого-то чувства [22].

В тоже время далеко не все люди, испытывающие трудности в саморегуляции своих эмоций, практикуют НССП. Важными для понимания этой взаимосвязи на наш взгляд являются данные полученные J.J. Muehlenkamp с коллегами [23]. Эти авторы считают, что между нарушением регуляции эмоций и несуицидальным самоповреждением своеобразным модератором выступает тело. Люди, участвующие в НССП имеют тенденцию обесценивать своё тело как важный аспект их самости, они меньше удовлетворены своим телом. Результаты этого исследования показывают, что только в контексте плохого отношения к собственному телу, эмоциональная дисрегуляция связана с НССП. Именно поэтому под «несуицидальным самоповреждающим поведением», чаще всего, понимают именно умышленное физическое повреждение тканей и органов своего тела, связанное с низким риском летального исхода, то есть без намерения умереть [24].

К наиболее распространённым способам самоповреждения относят удары по телу и повреждения кожи в виде расцарапывания или поверхностных надрезов, сделанных каким-либо острым предметом, располагающихся, как правило, параллельно на рассто- ences only between clinical groups of different types with different degrees of severity of selfinjuries, within the same continuum, is clearly insufficient. Studies show that a significant part of people with non-suicidal self-injury does not demonstrate clinically significant levels of mental dysfunction and the question of what makes non-suicidal self- injury deviating and qualitatively different from the norm remains open [17]. In this sense, the issue of the specifics of the period of adolescence is no less important. Aren't the features of mental functioning characteristic of a given age in themselves favorable ground for the formation of self-destructive manifestations, or are they largely due to a combination of the specific personal features and the reaction to life stress experienced by an individual. Thus, many researchers attribute the NSSI to a nonadaptive coping strategies used by people who are characterized with emotional dysregulation and who struggle with various emotional difficulties. Such adolescents report participating in non-suicidal self-injury primarily to reduce unbearable negative emotional or cognitive states, to punish themselves or to create at least some kind of feeling [22].

At the same time, not all people experiencing difficulties in self-regulation of their emotions practice NSSI. In our opinion, the data obtained by J.J. Muehlenkamp and colleagues is important for understanding this interconnection [23]. These authors believe that between the violation of the regulation of emotions and non-suicidal self-injury, the body acts as a kind of moderator. People involved in the NSSI tend to devalue their body as an important aspect of their self, they are less satisfied with their body. The results of this study show that only in the context of poor attitude towards one's own body, emotional dysregulation is associated with NSSI. That is why "non-suicidal self-injury", most often, is believed to mean intentional physical damage to the tissues and organs of your body associated with a low risk of death, that is without the intention to die [24].

The most common methods of self-injury include blows to the body and damage to the skin in the form of scratching or surface incisions made by any sharp object, usually located parallelly at a distance of about one or two centimeters from each other. In most cases, cuts are made on the hips, forearm, and side of the hands. Cuts can bleed and eventually form a scar system (DSM-5, 2013). Other common 
янии друг от друга примерно около одного, двух сантиметров. В большинстве случаев порезы делаются на бедрах, предплечье и боковой области рук. Порезы могут кровоточить, и со временем образовывать систему шрамов (DSM-5, 2013). Другие распространённые методы несуицидального самоповреждения, которые имеют ещё более низкие оценки летальности, включают нанесение ожогов и вмешательство в процесс заживления ран [25]. Другими словами, речь идёт о нарушении целостности телесных границ Я. Таким образом, именно телесное Я становится объектом самоагрессии при НССП. Взаимосвязь поверхности тела, то есть кожи и телесных ощущений с системой Я, была подмечена ещё 3. Фрейдом [26]. По его мнению, Я, прежде всего, телесно, оно происходит из телесных ощущений и главным образом из тех, что исходят от поверхности тела, а боль выполняет функцию формирования образа своего собственного тела. Идеи Фрейда получили дальнейшее развития в концепции Я-кожи Д.Анзьё, где особый акцент сделан на кожные переживания в развитии и формировании образа Я [27]. Как пишет в предисловии к книге Д. Анзьё, Эвелин Сешо: «Я-кожа» - это метафора, раскрывающая роль кожи в различных модальностях функций Я, проявляющихся на границе внутреннего и внешнего. Главной функцией Я-кожи является сохранение целостности Я, как вместилища феноменов психической жизни субъекта [28].

По мнению J. Carroll и соавт., люди, участвующие в несуицидальном самоповреждении, испытывают затруднение с разделением представления о себе от представлений о них значимых других, и кожа является основным барьером между человеком и его окружением, оставляя шрамы на коже, человек подтверждает свою идентичность и автономию [29].

Таким образом, можно предположить, что именно Я концепция, её элементы и сопровождающие её психологические феномены, являются наиболее уязвимыми психическими образованиями для самоагрессии лиц с НССП. Необходимо отметить, что актуальность изучения этого направления подтверждают и данные полученные многими авторами. Исследования лиц, участвующих в НССП позволяют говорить об их отрицательной самооценке, высокой самокритике, склонности чувствовать отверженность, испытывать гнев и ненависть по отношению к себе и другим [11, 30, 31]. Причём уровень ненависти к себе у людей, которые участвуют в несуицидальном самоповреждении, не только выше по сравнению с лицами, не практикующими самоповреждения, но они убеждены в том, что они плохие или дефектные, что, в свою очередь, связано с повышенной готовностью переносить физическую боль [32].

Цель исследования: изучение особенностей и methods of non-suicidal self-injury that have even lower mortality scores, include burns and intervention in wound healing [25]. In other words, we are talking about a violation of the integrity of the bodily boundaries of the Self. Thus, it is the physical Self that becomes the object of self-aggression in the NSSI. The relationship of the surface of the body, that is, the skin and bodily sensations with the Self, was noted even by Z. Freud [26]. In his opinion, I (the Self), first of all, is corporeal, it comes from bodily sensations, mainly from those that come from the surface of the body, and pain performs the function of forming the image of one's own body. Freud's ideas were further developed in D. Anzieu's concept of the I-skin, where special emphasis was placed on skin experiences in the development and formation of the image of the Self [27]. As Evelyn Sécho writes in the preface to the D. Anzieu's book: "I-skin" is a metaphor that reveals the role of the skin in various modalities of the functions of the Self that manifest themselves on the border between the internal and the external. The main function of the Iskin is to preserve the integrity of the Self, as a container for the phenomena of the mental life of the subject [28].

According to J. Carroll et al., people involved in non-suicidal self-injury experience difficulty in separating self-image from those of significant others, and the skin is the main barrier between the person and their environment; leaving scars on the skin, the person verifies their identity and autonomy [29].

Thus, it can be assumed that it is the I concept, its elements, and the psychological phenomena that accompany it are the most vulnerable mental formations for selfaggression of persons with NSSI. It should be noted that the relevance of studying this relation is also confirmed by the data obtained by many authors. Studies of people participating in NSSI allow us to talk about their negative self-esteem, high self-criticism, tendency to feel rejection, anger and hatred towards themselves and others [11, 30, 31]. Moreover, the level of self-hatred in people who participate in non-suicidal self-harm is not only higher than people who do not practice self-harm, but they are convinced that they are bad or defective, which, in turn, is associated with increased willingness to tolerate physical pain [32].

Objective: to study the characteristics and determinants of self-injury of adolescent 
детерминант самоповреждающего поведения девочек подростков на основе анализа различных элементов Яконцепции.

Характеристика выборки и методы исследования.

Отталкиваясь от анализа публикаций и данных, приведённых выше, в своём исследовании мы исходили из предположения о том, что Я-концепция лиц женского пола, практикующих самоповреждающее поведение, отличается от таковой у участниц контрольной группы, как по структуре взаимосвязей, входящих в неё элементов, так и по характеру их функционирования. В исследовании приняли участие 76 девушек в возрасте от 15 до 17 лет. Из них 37 - с различными проявлениями саморазрушающего поведения (основная группа), и 39 - здоровые (контрольная группа).

Отбор в основную группу осуществлялся по результатам консультативной работы, в том числе через социальные сети. В контрольную группу вошли добровольцы, обучающиеся в школе или среднеспециальных учебных заведениях. Вошедшие в основную группу подростки сообщили, что совершают преднамеренные самоповреждения более 2 лет, и за последний год произвели аутоагрессивные действия более 3 раз в виде порезов и повреждений кожи острыми предметами. В большинстве случаев (70\%) объектом самоповреждения являлись руки. Подростки отрицали наличие намерений умереть в момент самоповреждения, однако по самоотчетам мысли и фантазии на тему смерти присутствовали в это время достаточно часто. Все подростки, входящие в основную группу, состояли в открытых и закрытых группах / сообществах социальных сетей, связанных с темой самоповреждающего поведения и являлись их активными участниками (отмечали понравившиеся публикации, размещали понравившиеся публикации с изображением повреждения тела у себя на странице, вступали в обсуждения повреждений с другими участниками сообществ).

В контрольную группу вошли подростки без каких-либо поведенческих отклонений. Следует отметить, что подростки из контрольной группы в своей жизни сталкивались (видели и обсуждали) со случаями самоповреждающего поведения своих сверстников.

Предметом исследования стали отдельные свойства личности, Я-концепция, феномены Я, восходящие к разного рода проявлениям Я, таким как эгоизм (ценностные установки / ориентации в отношении других) и эгоцентризм (особенности мышления и система определения своего места в мире). Я-концепция, как осознаваемая система представлений индивида о самом себе, рассматривается нами в тесной связи с её неосознаваемыми эмоциональными компонентами. Для сравнительного исследования групп использовались girls based on the analysis of various elements of the self-concept.

Characteristics of the sample and research methods.

Based on the analysis of publications and the data presented above, in our study we proceeded from the assumption that the selfconcept of female practitioners of self-harming behavior differs from that of the participants in the control group, both in the structure of relationships of its elements, and the nature of their functioning. The study involved 76 girls aged 15 to 17 . Of these, 37 had various manifestations of self-destructive behavior (main group), and 39 were healthy (control group).

Selection to the main group was carried out according to the results of consultative work, including social media. The control group was made up of volunteers studying at schools or secondary special educational institutions. The adolescents who entered the main group reported that they commit deliberate self-harm for more than 2 years and over the past year have performed auto-aggressive actions more than 3 times in the form of cuts and damage to the skin with sharp objects. In most cases $(70 \%)$, the object of self-harm was hands. Teenagers denied the intention to die at the time of self-harm, but according to selfreports thoughts and fantasies about death were present at this time quite often. All adolescents in the main group were subscribed to open and closed groups/communities in social media that were associated with the same selfinjury and were active participants (liked the publications, reposted the publications they liked with the image of body damage on their page, entered into discussions about injuries with other community members).

The control group included adolescents without any behavioral abnormalities. It should be noted that adolescents from the control group have encountered (seen and discussed) cases of self-harming behavior of their peers in their regular lives.

The subject of the study were certain individual personality traits, the I-concept, phenomena of the Self that are seen as various manifestations of Self, such as selfishness (value attitudes/orientations in relation to others) and self-centeredness (thinking features and the system for determining one's place in the world). The self-concept, as a conscious system of the individual's self-representations, is considered by us in close connection with its unconscious emotional components. For a 
следующие методики:

1. Клиническая беседа.

2. «Тест-Опросник Самоотношения» [33], позволяющий выявить уровень самоотношения и оценить выраженность отдельных аспектов самоотношения.

3. «Опросник образа собственного тела» [34], направленный на диагностику недовольства собственным телом.

4. Методика «Шкала диспозиционного эгоизма» К. Муздыбаева [35], направленная на диагностику уровня эгоизма.

5. Методика «Суверенность психологического пространства» С.К. Нартовой-Бочавер для исследования различных аспектов суверенности психологического пространства [36].

6. Методика «Hand-test» / «Тест-руки» Э. Вагнера в адаптации Т.Н. Курбатовой [37], направленная на глубинное исследование личности и прогноз склонности человека к открытому агрессивному поведению.

7. Проективная методика «Автопортрет» [38] для диагностики бессознательных эмоциональных компонентов личности.

8. Тест Эгоцентрических ассоциаций (ЭАТ) [39] для диагностики уровня эгоцентрической направленности личности.

В целях количественной обработки материала, в исследовании использовались параметрические методы математической статистики. Они представлены сравнительным анализом с использованием критерия Стъюдента и корреляционным анализом по методу Пирсона.

Статистическая обработка данных проводилась с использованием пакета программ SPSS-21.

Результаты исследования.

Данные о социально-демографических и биографических характеристиках лиц обеих групп представлены в таблице 1 .

Как видно из таблицы, среди обследованных лиц с самоповреждающим поведением у $81,1 \%$ есть братья / сестры; среди них наибольшее количество среднерождённых - 43,2\%; в большинстве случаев их воспитывает один родитель $-56,8 \%$.

В этой группе достоверно $(\mathrm{P}<0,05)$ больше тех, кто за последние 3 года серьёзно конфликтовал с родителями (уходил из дома, скрывал от родителей совершенное правонарушение, похищал у родителей деньги и т.п.) - 73,0\%. В основной группе также больше тех, кто демонстрировал признаки школьной дезадаптации - 56,8\% (ссорился с одноклассниками и учителями, подвергался травле со стороны одноклассников, оставался на второй год, пропускал школу без причины, получал неудовлетворительные итоговые оценки и пр.). comparative study of the groups, the following methods were used:

1. Clinical conversation.

2. "Test Questionnaire of Self-Attitude" [33], which allows to identify the level of selfattitude and assess the severity of individual aspects of self-attitude.

3. "Questionnaire of the image of one's own body" [34], aimed at diagnosing dissatisfaction with one's own body.

4. The methodology "Scale of dispositional selfishness" by K. Muzdybaev [35], aimed at diagnosing the level of selfishness.

5. Methodology "Sovereignty of the psychological space" S.K. Narto-howl-Bochaver for the study of various aspects of the sovereignty of the psychological space [36].

6. Methodology "Hand-test" by E. Wagner in the adaptation of T.N. Kurbatova [37], aimed at an in-depth study of the personality and prediction of a person's tendency to open aggressive behavior.

7. The projective technique "Selfportrait" [38] for the diagnosis of unconscious emotional components of the personality.

8. Egocentric associations test (EAT) [39] for the diagnosis of the level of egocentric orientation of personality.

In order to quantitatively process the material, the study used parametric methods of mathematical statistics. They are presented by comparative analysis using the Student criterion and Pearson's correlation analysis. Statistical data processing was performed using the SPSS-21 software package.

The results of the study.

Data on the socio-demographic and biographical characteristics of persons of both groups are presented in table 1.

As can be seen from the table, among the examined individuals with self-injury, $81.1 \%$ have siblings; most are middle-born $-43.2 \%$; predominantly they are raised by a single parent $-56.8 \%$.

In this group, there were significantly $(\mathrm{P}<0.05)$ more individuals who over the past 3 years had serious conflicts with their parents (leaving home, hiding a committed offense from their parents, stealing money from their parents, etc.) $-73.0 \%$. In the main group there are also more of those who showed signs of school maladaptation - 56.8\% (had conflicts with classmates and teachers, were bullied by classmates, had to go to the same grade twice, missed school for no reason, received unsatisfactory final grades etc.). 
Таблица 1 / Table 1

Социально-демографические и биографические характеристики лиц основной и контрольной групп

Socio-demographic and biographical characteristics of persons of the main and control groups

\begin{tabular}{|c|c|c|c|c|c|}
\hline \multirow{2}{*}{\multicolumn{2}{|c|}{ Показатель / Indicator }} & \multicolumn{2}{|c|}{$\begin{array}{l}\text { Основная группа } \\
\text { Main group }(\mathrm{n}=37)\end{array}$} & \multicolumn{2}{|c|}{$\begin{array}{l}\text { Контрольная группа } \\
\text { Control group }(\mathrm{n}=39)\end{array}$} \\
\hline & & $\mathrm{n}$ & $\%$ & $\mathrm{n}$ & $\%$ \\
\hline \multirow{2}{*}{$\begin{array}{l}\text { Братья / Сестры } \\
\text { Siblings } \\
\end{array}$} & Единственный ребёнок / Only child & $* 7$ & 18,9 & 16 & 41,1 \\
\hline & Есть сиблинги / Has siblings & $* 30$ & 81,1 & 23 & 58,9 \\
\hline \multirow{3}{*}{$\begin{array}{l}\text { Порядок рождения } \\
\text { The order of birth }\end{array}$} & Старший / Eldest & $* 10$ & 27,1 & 16 & 41,0 \\
\hline & Средний / Middle & $* 16$ & 43,2 & 11 & 28,2 \\
\hline & Младший / Youngest & 11 & 29,7 & 12 & 30,8 \\
\hline \multirow{2}{*}{$\begin{array}{l}\text { Семейное окружение } \\
\text { Family }\end{array}$} & Оба родителя / Both parents & $* 16$ & 43,2 & 34 & 87,2 \\
\hline & Один родитель / One parent & $* 21$ & 56,8 & 5 & 12,8 \\
\hline $\begin{array}{l}\text { Проблемы в семье } \\
\text { Family problems } \\
\end{array}$ & $\begin{array}{l}\text { Частые конфликты с родственниками } \\
\text { Frequent conflicts }\end{array}$ & $* 27$ & 73,0 & 6 & 15,4 \\
\hline $\begin{array}{l}\text { Проблемы в учёбе } \\
\text { Academic issues }\end{array}$ & $\begin{array}{l}\text { Оставался на второй год, ссоры } \\
\text { с одноклассниками и учителями } \\
\text { Had to go to the same grade twice, } \\
\text { conflicts with classmates and teachers }\end{array}$ & $* 21$ & 56,8 & 4 & 10,3 \\
\hline
\end{tabular}

Примечание / Note: $* \mathrm{P}<0,05$

Беседа с подростками, входящими в основную группу, позволяет говорить о преобладании у них проблем с самоконтролем в эмоционально-волевой сфере, они внушаемы, впечатлительны плохо организованны, их отношение к учёбе чаще зависит от настроения, они ориентированы на быстрое удовлетворение возникающих желаний, склонны к риску, плохо прогнозируют последствие своих действий, в значительной степени зависимы от мнения других, нуждаются во внимании к себе, и, в тоже время, им сложно поддерживать длительные дружеские контакты.

На следующем этапе исследования, нами был проведен уровневый анализ психологических характеристик основной и контрольной групп на основе использования параметрического статистического критерия (Т-критерия Стъюдента) для независимых выборок. В исследовании учитывались только те значения, которые укладывались в диапазон значений $\mathrm{P} \leq 0,05$ (табл. 2).

Результаты анализа позволяют предположить, что самоотношение, в целом у девушек основной группы, является более негативным, что подтверждается выраженными показателями самообвинения, низкими показателями самоуважения, аутосимпатии, самоинтереса и позитивного ожидаемого отношения от других. Подобная тенденция прослеживается и в структуре отношения к собственному телу, которая проявляет себя в выраженном повышении показателей недовольства собственным телом.

Сравнительный анализ ядерных образований личности также показал значительные различия между группами (табл. 3).
An interview with adolescents in the main group allows us to talk about the predominance of problems with self-control in the emotional-volitional sphere: they are suggestible, impressionable, poorly organized, their attitude to learning depends more often on their mood, they are focused on the quick satisfaction of arising desires, prone to risk, poorly predict the consequences of their actions, largely depend on the opinions of others, need attention to themselves, and, at the same time, it is difficult for them to maintain longterm friendly contacts.

At the next stage of the study, we carried out a level analysis of the psychological characteristics of the main and control groups based on the use of the parametric statistical criterion (Student's T-test) for independent samples. The study only considered those values that fit into the range of value $\mathrm{P} \leq 0.05$ (table. 2).

The results of the analysis suggest that self-attitude, in general, among girls of the main group, is more negative, which is confirmed by pronounced indicators of selfaccusation, low rates of self-esteem, selfsympathy, self-interest and positive expected attitude from others. A similar tendency is also observed in the structure of attitude towards one's own body, which manifests itself in a pronounced increase in indices of discontent with one's own body.

A comparative analysis of the nuclear formations of the individual also showed significant differences between the groups (Table 3). 
Таблица 2 / Table 2

Сравнение показателей опросника Самоотношения и опросника «Образ собственного тела» [33, 34],

(первичные показатели представлены в виде накопленных частот / баллов при $\mathrm{N}_{1}=37, \mathrm{~N}_{2}=39$ )

Comparison of the indicators of the Self-Attitude questionnaire and the "Image of one's own body" questionnaire

$[33,34]$, (the primary indicators are presented in the form of accumulated frequencies / points at $\mathrm{N}_{1}=37, \mathrm{~N}_{2}=39$ )

\begin{tabular}{|c|c|c|c|c|}
\hline $\begin{array}{c}\text { Шкалы опросника Самоотношения } \\
\text { Self-attitude Questionnaire Scales }\end{array}$ & $\begin{array}{c}\text { Основная } \\
\text { группа } \\
\text { Main group }\end{array}$ & $\begin{array}{c}\text { Контрольная } \\
\text { группа } \\
\text { Control group } \\
\end{array}$ & $\begin{array}{c}\text { Т-критерий Стъюдента } \\
\text { (абсолютное значение) } \\
\text { Student's t-test } \\
\end{array}$ & $\mathrm{P}$ \\
\hline Глобальное самоотношение / Global self-attitude & 24,84 & 78,35 & $-12,593$ & $<0,001$ \\
\hline Самоуважение / Self-respect & 19,27 & 70,90 & $-11,190$ & $<0,001$ \\
\hline Аутосимпатия / Self-sympathy & 33,35 & 61,54 & $-5,628$ & $<0,001$ \\
\hline $\begin{array}{l}\text { Ожидаемое отношение от других } \\
\text { Expected attitude from others }\end{array}$ & 12,74 & 46,82 & $-6,943$ & $<0,001$ \\
\hline Самоинтерес / Self-interest & 38,61 & 78,87 & $-6,855$ & $<0,001$ \\
\hline Самоуверенность / Self-confidence & 31,16 & 62,00 & $-5,817$ & $<0,001$ \\
\hline Отношение других / Attitude from others & 12,35 & 32,28 & $-5,084$ & $<0,001$ \\
\hline Самопринятие / Self-acceptance & 39,38 & 73,05 & $-5,858$ & $<0,001$ \\
\hline Самопоследовательность / Self-consistency & 30,92 & 61,21 & $-7,271$ & $<0,001$ \\
\hline Самообвинение / Self-accusation & 83,68 & 47,18 & 7,084 & $<0,001$ \\
\hline Самоинтерес / Self-interest & 36,65 & 73,33 & $-6,184$ & $<0,001$ \\
\hline Самопонимание / Self-understanding & 28,16 & 71,36 & $-7,500$ & $<0,001$ \\
\hline $\begin{array}{l}\text { Неудовлетворённость собственным телом } \\
\text { Dissatisfaction with own body }\end{array}$ & 7,83 & 6,08 & 5,322 & $<0,001$ \\
\hline
\end{tabular}

Из таблицы 3 видно, что в основной группе показатели уровня эгоизма ниже, а показатели эгоцентризма значительно выше, по сравнению с контрольной группой, что может говорить о выраженности признака крайней сосредоточенности на своём «Я» и в тоже время меньшей любви к себе, ориентации на социум. Подобная тенденция подтверждается анализом личностных границ несовершеннолетних.
Table 3 shows that in the main group the indicators of the level of selfishness are lower, and the indicators of self-centeredness are significantly higher compared to the control group, which can indicate the severity of the sign of extreme focus on one's Self and at the same time less love for oneself, orientation to the community.

Таблица 3 / Table 3

Сравнение показателей эгоизма и эгоцентризма и показателей по методике «Суверенность психологического пространства личности» $[35,36,39]$ (первичные показатели представлены в баллах при $\mathrm{N}_{1}=37, \mathrm{~N}_{2}=39$ )

Comparison of the indicators of selfishness and self-centeredness and indicators by the method of "Sovereignty of the

psychological space of the individual" $[35,36,39]$ (primary indicators are presented in points at $\mathrm{N}_{1}=37, \mathrm{~N}_{2}=39$ )

\begin{tabular}{|c|c|c|c|c|}
\hline Показатель / Indicator & \begin{tabular}{|c|} 
Основная \\
группа \\
Main group \\
\end{tabular} & $\begin{array}{c}\text { Контрольная } \\
\text { группа } \\
\text { Control group } \\
\end{array}$ & $\begin{array}{c}\text { Т-критерий Стъюдента } \\
\text { (абсолютное значение) } \\
\text { Student's t-test } \\
\end{array}$ & $\mathrm{P}$ \\
\hline Эгоизм / Selfishness & 31,49 & 36,41 & $-2,219$ & $<0,03$ \\
\hline Эгоцентризм / Self-centeredness & 24,22 & 12,05 & 8,224 & $<0,001$ \\
\hline $\begin{array}{l}\text { Суверенность физического тела } \\
\text { Physical body sovereignty }\end{array}$ & $-24,89$ & 15,54 & $-5,044$ & $<0,001$ \\
\hline Суверенность территории / Territorial sovereignty & $-16,16$ & 29,23 & $-6,564$ & $<0,001$ \\
\hline $\begin{array}{l}\text { Суверенность личных вещей } \\
\text { Sovereignty of personal items }\end{array}$ & $-9,75$ & 25,72 & $-5,082$ & $<0,001$ \\
\hline $\begin{array}{l}\text { Суверенность социальных связей } \\
\text { Sovereignty of social connections }\end{array}$ & $-29,08$ & 23,18 & $-5,342$ & $<0,001$ \\
\hline Суверенность ценностей / Sovereignty of values & $-6,16$ & 25,62 & $-3,774$ & $<0,001$ \\
\hline $\begin{array}{l}\text { Суверенность психологического пространства } \\
\text { The sovereignty of psychological space }\end{array}$ & $-9,00$ & 24,50 & $-5,622$ & $<0,001$ \\
\hline
\end{tabular}


Так, в основной группе респондентов показатели суверенности физического тела, суверенности территории (обеспечение социальной идентичности, возможность контролировать интенсивность социальных контактов и пр.), суверенности личных вещей (средства самопрезентации, ресурс самоподдержки и пр.), суверенности социальных связей (установление отношений психологической интимности, обретение личной и социальной идентичности и пр.), суверенности ценностей (обеспечение личной ответственности, экзистенциальной уверенности и пр.) и суверенности психологического пространства значительно ниже нормы и значимо ниже по сравнению с контрольной группой, что в целом говорит о депривированности этих измерений психологического пространства у де-

Для подтверждения полученных фактов были использованы данные проективных методик, ориентированных на личностные и поведенческие особенности девушек, которые представлены в таблице 4. вушек с самоповреждающим поведением.

A similar trend is confirmed by an analysis of the personal boundaries of the underaged. So, in the main group of respondents, indicators of the sovereignty of the physical body, the sovereignty of the territory (ensuring social identity, the ability to control the intensity of social contacts, etc.), the sovereignty of personal things (self-presentation tools, selfsupport resource, etc.), sovereignty of social connections (establishing relationships of psychological intimacy, gaining personal and social identity, etc.), sovereignty of values (ensuring personal responsibility, existential confidence, etc.) and sovereignty of psychological space are considerably below the norm and significantly lower compared to the control group, which in general shows deprivation of these psychological space measurements for the girls with self-harming behavior.

To confirm the data obtained, we used the data of projective methods focused on the personality and behavioral characteristics of girls, which are presented in table 4.

таблица 4 / Table 4

Сравнение показателей по проективной методике «Автопортрет» и «Наnd-тест» [37, 38], (первичные показатели представлены в баллах при $\mathrm{N}_{1}=37, \mathrm{~N}_{2}=39$ ) / Comparison of indicators according to the projective methodologies "Self-portrait" and "Hand-test" [37, 38], (primary indicators are presented in points at $\mathrm{N}_{1}=37, \mathrm{~N}_{2}=39$ )

\begin{tabular}{|c|c|c|c|c|}
\hline Показатель / Indicator & $\begin{array}{l}\text { Основная } \\
\text { группа } \\
\text { Main group }\end{array}$ & $\begin{array}{l}\text { Контрольная } \\
\text { группа } \\
\text { Control group } \\
\end{array}$ & $\begin{array}{c}\text { Т-критерий } \\
\text { Стъюдента } \\
\text { Student's t-test } \\
\end{array}$ & $\mathrm{P}$ \\
\hline Адекватная самооценка / Adequate self-esteem & 0,97 & 2,00 & $-3,993$ & $<0,001$ \\
\hline $\begin{array}{l}\text { Неуверенность в себе, потребность в одобрении и под- } \\
\text { держке / Self-doubt, need for approval and support }\end{array}$ & 1,08 & 0,41 & 2,708 & $<0,008$ \\
\hline $\begin{array}{l}\text { Сниженная самооценка, негативное отношение к себе, } \\
\text { чувства незащищенности / Decreased self-esteem, nega- } \\
\text { tive self-image, feelings of insecurity }\end{array}$ & 1,22 & 0,23 & 4,722 & $<0,001$ \\
\hline $\begin{array}{l}\text { Конкретность, оптимизм, высокий уровень энергии и } \\
\text { стремлений / Concreteness, optimism, a high level of } \\
\text { energy and aspirations }\end{array}$ & 0,05 & 0,54 & $-3,044$ & $<0,003$ \\
\hline Аутичность, замкнутость / Autism, isolation & 0,54 & 0,07 & 2,898 & $<0,005$ \\
\hline Неадекватность / Inadequacy & 0,45 & 0,00 & 3,576 & $<0,001$ \\
\hline Инфантилизм / Infantilism & 0,73 & 0,28 & 2,259 & $<0,027$ \\
\hline Аутоагрессия / Autoagression & 1,35 & 0,00 & 3,467 & $<0,001$ \\
\hline $\begin{array}{l}\text { Степень личностной дезадаптации } \\
\text { The degree of personal maladaptation }\end{array}$ & 1,41 & 0,64 & 2,784 & $<0,007$ \\
\hline $\begin{array}{l}\text { Подозрительность, гиперчувствительность к мнению } \\
\text { окружающих и критике / Suspicion, hypersensitivity to the } \\
\text { opinions of others and criticism }\end{array}$ & 1,32 & 0,72 & 2,250 & $<0,027$ \\
\hline Эмоциональная незрелость / Emotional immaturity & 1,11 & 0,31 & 3,539 & $<0,029$ \\
\hline $\begin{array}{l}\text { Демонстративность, эгоизм (Рер) } \\
\text { Demonstration, selfishness (Pep) } \\
\end{array}$ & 2,92 & 1,13 & 2,224 & $<0,001$ \\
\hline Тревога/напряжение (Ten) / Anxiety, tension (Ten) & 4,43 & 1,26 & 4,073 & $<0,001$ \\
\hline $\begin{array}{l}\text { Активные безличные ответы (Act) } \\
\text { Active impersonal answers (Act) }\end{array}$ & 24,14 & 32,67 & $-3,028$ & $<0,003$ \\
\hline Дезадаптация (MAL) / Maladaptation (MAL) & 1,68 & 1,08 & 2,151 & $<0,035$ \\
\hline
\end{tabular}


Из полученных статистически значимых результатов, представленных в таблице 4 видно, что девушкам с самоповреждающим поведением в отличие от контрольной группы более свойственны повышенные показатели по аутоагрессии, неуверенность в себе и тревожность, а также сниженная самооценка, эмоциональная незрелость (инфантилизм), неадекватность, замкнутость и в тоже время, потребность в общении с другими людьми, демонстративность, повышенная чувствительность к критике со стороны других. Девушкам контрольной группы более свойственна адекватная самооценка, а также конкретность, оптимизм, высокий уровень энергии и стремлений.

Анализ результатов Hand-теста указывает на более высокие показатели личностной дезадаптации и напряжения у представителей основной выборки, которые могут говорить об эмоциональной неустойчивости и неспособности адекватно и целенаправленно реагировать в условиях психотравмирующей ситуации.

Сниженный показатель активных безличных ответов у подростков с самоповреждающим поведением, свидетельствует о повышенной социальной восприимчивости, тревожности и чувствительности в межличностных взаимоотношениях. У подростков с нормативным поведением, напротив, повышенный показатель активных безличных ответов может указывать на меньшую насторожённость в отношении социальной среды, предполагая меньшую конфликтность в процессе социальной интеграции.

Однако, поскольку сравнительный анализ результатов методик не позволяет ответить на вопрос о детерминантах формирования данных видов поведения, а также направлениях коррекции, основанных на знании подобных «запускающих» данный процесс механизмax, на следующем этапе исследования нами был проведён структурный анализ проблемы, в основание которого был положен анализ корреляций (табл. 5).

Как видно из таблицы, в первую плеяду вошли взаимосвязи показателей методик «Автопортрет», «Опросник образа собственного тела» и «ТестОпросника Самоотношение», обуславливающих проявление аутоагрессии. При этом показатель аутоагрессии у лиц с самоповреждающим поведением положительно взаимосвязан с ожиданием положительного (или отрицательного) отношения от других и самоинтересом (на уровне тенденции) с одной стороны и недовольством своим собственным телом, с другой. Причём более высокие показатели самоинтереса взаимосвязаны с высокими показателями демонстративности, а недовольство своим телом - с ожидаемым отношением от других. При этом последняя связь является положительной.
From the statistically significant results obtained, presented in Table 4, it is clear that girls with self-injury, in contrast to the control group, tend to possess increased indicators of auto-aggression, self-doubt and anxiety, while indicators of self-esteem, emotional immaturity (infantilism), inadequacy, isolation are reduced, accompanied with the need for communication with other people, demonstrativeness, and increased sensitivity to criticism from others. For the control group girls adequate self-esteem, as well as concreteness, optimism, high level of energy and aspirations are more typical.

The analysis of the results of the Handtest indicates higher indices of personal maladaptation and tension among the representatives of the main sample, which can indicate emotional instability and the inability to adequately and purposefully react in a traumatic situation.

Reduced rate of active impersonal responses in adolescents with self-harming behavior indicates increased social susceptibility, anxiety and sensitivity in interpersonal relationships. In adolescents with normative behavior, on the contrary, increased rate of active impersonal responses may indicate lower anxiety in social environment, suggesting less conflict in the process of social integration.

However, since the comparative analysis of the results of the methods does not let us answer the question about the determinants of the formation of these types of behavior, as well as the directions of correction based on the knowledge of such mechanisms that trigger this process, at the next stage of the study, we carried out a structural analysis of the problem, which was based on the analysis of correlations (table. 5).

As can be seen from the table, the first group included the interconnections of the indicators of the Self-Portrait, Self-image of the Self-image Questionnaire and Self-Attitude Test Questionnaire, which determine the manifestation of auto-aggression. Moreover, the indicator of auto-aggression in individuals with self-harming behavior is positively interconnected on the one hand with the expectation of a positive (or negative) attitude from others and self-interest (at the level of a trend) and dissatisfaction with one's own body on the other. Moreover, higher self-interest indicators are interconnected with high levels of demonstrativeness, and dissatisfaction with one's body with the expected attitude from others. That connection is positive. 
Таблий 5/ Table 5

Корреляционный анализ взаимосвязей склонности к самоповреждающему поведению и личностных особенностей в основной группе $\left(\mathrm{N}_{1}=37\right)$ / Correlation analysis of the relationship of propensity to self-injury and personality traits in the main group $\left(\mathrm{N}_{1}=37\right)$

\begin{tabular}{l|l|c}
\hline \multicolumn{1}{c|}{ Показатели / Indicators } & \multicolumn{1}{c|}{ Корреляционные взаимосвязи / Correlation relationships } & P \\
\hline \multicolumn{3}{c|}{ Анализ первой плеяды / Analysis of the first group } \\
\hline \begin{tabular}{l|l} 
Аутоагрессия \\
Autoagression
\end{tabular} & $\begin{array}{l}\text { Недовольство собственным телом / Dissatisfaction with own body } \\
\text { Ожидаемое отношение от других / Expected Attitude from Others }\end{array}$ & $0,01 * *$ \\
\hline $\begin{array}{l}\text { Недовольство собственным телом } \\
\text { Dissatisfaction with оwn body }\end{array}$ & Ожидаемое отношение от других & $0,05^{*}$ \\
\hline Демонстративность & Ехресted Attitude from Others & $0,01 * *$ \\
Demonstrativeness & Самоинтерес & \\
\hline
\end{tabular}

Анализ второй плеяды / Analysis of the second group

\begin{tabular}{|c|c|c|}
\hline $\begin{array}{l}\text { Желание сотрудничать с другими } \\
\text { Desire to collaborate with others }\end{array}$ & $\begin{array}{l}\text { Самопонимание / Self-understanding } \\
\text { Самоуважение / Self-respect } \\
\text { Самоуверенность / Self-confidence }\end{array}$ & $\begin{array}{l}-0,01 * * \\
-0,01 * * \\
-0,05 *\end{array}$ \\
\hline $\begin{array}{l}\text { Самоуверенность } \\
\text { Self-confidence }\end{array}$ & $\begin{array}{l}\text { Готовность к проявлению открытой агрессии } \\
\text { Willingness to manifest open aggression }\end{array}$ & $0,01 * *$ \\
\hline $\begin{array}{l}\text { Готовность к проявлению } \\
\text { открытой агрессии / Willingness } \\
\text { to manifest open aggression }\end{array}$ & $\begin{array}{l}\text { Самопринятие } \\
\text { Self-acceptance }\end{array}$ & $0,01 * *$ \\
\hline
\end{tabular}

Анализ третьей плеяды / Analysis of the third group

\begin{tabular}{l|l|c}
\hline Эгоцентризм & Повышенная чувствительность к критике & $0,01^{* *}$ \\
Self-centeredness & Нуреrsensitivity to Criticism & $0,01^{* *}$ \\
& Недовольство собственным телом / Dissatisfaction with own body & $-0,01^{* *}$ \\
& Суверенность социальных связей / Sovereignty of social ties & $-0,01^{* *}$ \\
\hline Недовольство собственным телом & Эгоцзм / Selfishness & $0,01^{* *}$ \\
Dissatisfaction with оwn body & Эгоизм / Selfishness & $-0,05^{*}$ \\
& Чувство неполноценности / Sense of inferiority & $-0,01^{* *}$ \\
\hline Чувство неполноценности & Эгоизм / Selfishness & $-0,01^{* *}$ \\
Sense of inferiority & & \\
\hline
\end{tabular}

Примечание / Note: ${ }^{*} \mathrm{P}<0,05 ; * * \mathrm{P}<0,01$

Исходя из этого, можно говорить, что риск самоповреждения у данной категории подростков обусловлен, прежде всего, неудовлетворённостью своим телом, повышенным вниманием к себе самому и одновременно стремлением привлечь к себе и своим проблемам внимание окружающих. Неудовлетворённость своим телом определяет аутоагрессию и формирует ожидаемое отношение от окружающих.

Во вторую плеяду показателей основной группы респондентов вошли взаимосвязи параметров самоотношения и готовности проявлять открытую агрессию, а также желание сотрудничать с другими людьми. Исходя из структуры данных взаимосвязей, можно сказать, что проявление открытой агрессии у подростков контрольной группы взаимосвязано с повышением самопринятия и самоуверенности, что в свою очередь определяет снижение желания сотрудничества с другими людьми. Последняя тенденция сохраняется с ростом
Based on this, it can be said that the risk of self-harm in this category of adolescents first of all grounds on dissatisfaction with their bodies, increased attention to themselves and at the same time the desire to attract the attention of others to themselves and their problems. Dissatisfaction with the body determines auto-aggression and forms the expected attitude from others.

The second group of indicators for the respondents of the main group included interconnections of the parameters of self-attitude and willingness to show open aggression, as well as the desire to cooperate with other people. Based on the structure of these relationships, we can say that the manifestation of open aggression in adolescents in the control group is interconnected with an increase in self-acceptance and self-confidence, which in turn determines a decrease in the desire for cooperation with other people. The latter trend 
самопонимания и самоуважения.

Анализ взаимосвязей третьей плеяды, в первую очередь, позволяет говорить о разной роли проявления эгоизма и эгоцентризма в структуре Я-концепции лиц с НССП. Во-вторых, можно предположить, что эгоизм, в большей мере связанный с системой отношений субъекта, имеет прямой выход, как на чувство неполноценности, так и на недовольство своим телом, которые значительно ниже при высоких показателях эгоизма. В свою очередь, эгоцентризм, который имеет отношение к внутренним составляющим Я, имеет положительные связи с отношением к своему телу и чувствительностью к критике.

Дальнейший анализ корреляционных связей в контрольной группе девушек, не склонных к самоповреждающему поведению, показал несколько иную структуру корреляций (табл. 6).

Как показывает исследование, глобальное самоотношение респондентов данной группы обратно пропорционально неудовлетворённости своим телом, а самообвинение сочетается со снижением показателей суверенности территории. Последнее говорить о том, что самоотношение выступает здесь частью механизма сдерживания и противовесом в регуляции восприятия образа себя, и предупреждает нарушение границ приватного пространства личности.

Анализ взаимосвязей во второй плеяде указывает на тот факт, что недовольство своим телом тем выше, чем ниже уровень аутосимпатии и самоуверенности, которые, однако, в нормативной выборке отличаются достаточно выраженными показателями.

continues with the growth of self-understnding and self-esteem.

An analysis of the interconnections of the third group allows us to talk about the different roles of manifestation of selfishness and self-centeredness in the structure of the selfconcept of individuals with NSSI. Secondly, it can be assumed that selfishness, which is more associated with the system of relations of the subject, has direct influence both on the sense of inferiority and on the dissatisfaction with one's body, which are much lower with high rates of selfishness. In turn, self-centeredness that is related to the internal components of the Self has positive connections with the attitude to one's body and sensitivity to criticism.

Further analysis of correlation in the control group of girls who are not prone to selfharm showed a slightly different structure of correlations (Table 6).

As the study shows, the global selfattitude of the respondents of this group is inversely proportional to dissatisfaction with their body, and self-incrimination is combined with a decrease in the sovereignty of the territory. The latter suggests that self-attitude is part of the deterrence mechanism and a counterbalance in the regulation of perception of the image of oneself, and there is a violation of the boundaries of the personal space of the individual.

An analysis of the interconnections in the second group indicates the fact that dissatisfaction with one's body is higher if the level of autosympathy and self-confidence is lower which, however, are quite pronounced in the normative sample.

Таблица 6 / Table 6

Корреляционный анализ взаимосвязей склонности к самоповреждающему поведению и личностных особенностей в контрольной группе $\left(\mathrm{N}_{2}=39\right)$ / Correlation analysis of the relationship of propensity to self-injurious behavior and personality traits in the control group $\left(\mathrm{N}_{2}=39\right)$

\begin{tabular}{l|l|c}
\hline \multicolumn{1}{c|}{ Показатели / Indicators } & \multicolumn{1}{c|}{ Корреляционные взаимосвязи / Correlation relationships } & P \\
\hline \multicolumn{2}{c}{ Анализ первой плеяды / Analysis of the first group } & $-0,01 * *$ \\
\hline $\begin{array}{l}\text { Неудовлетворённость собственным телом } \\
\text { Dissatisfaction with own body }\end{array}$ & $\begin{array}{l}\text { Глобальное самоотношение } \\
\text { Global self-attitude }\end{array}$ & $-0,01 * *$ \\
\hline Самообвинение / Self-accusation & Суверенность территории / Sovereignty of territory & \\
\hline
\end{tabular}

Анализ второй плеяды / Analysis of the second group

\begin{tabular}{l|l|c}
\hline Недовольство собственным телом & Аутосимпатия / Self-sympathy & $-0,01^{* *}$ \\
Dissatisfaction with own body & Самоуверенность / Self-confidence & $-0,05^{*}$ \\
\hline & Самоуважение / Self-respect & $-0,05^{*}$ \\
Тревожность, неуверенность в себе & Самопонимание / Self-understanding & $-0,01^{* *}$ \\
Anxiety, self-doubt & Самоуверенность / Self-confidence & $-0,01^{* *}$ \\
& Аутосимпатия / Self-sympathy & $-0,05^{*}$ \\
\hline Уровень энергии и стремлений & Самоуважение / Self-respect & $0,01^{* *}$ \\
Level of energy and aspirations & Эгоизм / Selfishness & $0,01^{* *}$ \\
\hline
\end{tabular}

Примечание / Note: *P $<0,05 ; * * \mathrm{P}<0,01$ 
В свою очередь, сам показатель неуверенности, связанный с высокими показателями тревожности имеет выход на все структурные компоненты Яконцепции, включая самоуважение, самопонимание, самоуверенность. По всей видимости, значительную роль в структуре самоуважения и эгоистических стремлений выстроить положительный образ себя в глазах окружающих, играет и общий уровень энергии и стремлений, который значительно выше, у людей, у которых не возникает проблем с самоповреждением.

Обсуждение и выводы.

Общий анализ статистических параметров выборки девочек-подростков, склонных к самоповреждающему поведению, показал, что чаще всего, к подобным формам поведения склонны средне-рождённые дети (порядок рождения), воспитанные в неблагоприятной семейной обстановке. Данные подтверждаются работами отдельных отечественных и зарубежных авторов [20, 40]. Однако противоречат работам C. Ernst и J. Angst, которые указывают на отсутствие однозначной связи данной проблемы с порядком рождения [41]. Возрастные особенности, по всей видимости, не играют значительной роли в формировании самоповреждающего поведения.

В свою очередь, анализ психологических характеристик позволил сделать вывод о значительной связи Я-концептуальных составляющих и склонности к проявлению саморазрушающих видов поведения. Более того, спектр личностных характеристик, связанных с особенностями самоповреждающего поведения девушек оказался достаточно широким. Так подростки, демонстрирующие подобные признаки в поведении проявляют и явные симптомы негативного отношения к себе, более эгоцентричны. Им свойственны неуверенность в себе и тревожность, эмоциональная незрелость, демонстративность, потребность в общении с другими людьми и, в тоже время, повышенная чувствительность к критике со стороны других. Многие показатели суверенности психологического пространства этих подростков, депривированны, что вызывает у них чувство отстранённости от реальности, самоотчуждённости и фрагментарности собственной жизни, создает проблемы в выборе объектов самоидентификации.

В свою очередь, депривированность представляет собой результат и условие пониженной личностной эффективности, и сочетается с разными формами дезадаптации, приводя к ослаблению личной ответственности, к неспособности принимать решения [36]. Она характеризуется нарушениями в эмоциональной регуляции, склонностью к самообвинениям, переходящим в стресогенных ситуациях в аутоагрессивные действия. Интересным является тот факт, что такие особенности
In turn, the indicator of self-doubt itself is associated with high indicators of anxiety and has access to all the structural components of the self-concept, including self-esteem, selfunderstanding, self-confidence. Apparently, a significant role in the structure of self-esteem and selfish aspirations to build a positive image of oneself in the eyes of others is played by the general level of energy and aspirations, which is much higher for people who do not have problems with self-harm.

Discussion and conclusions.

A general analysis of the statistical parameters of a sample of teenage girls prone to self-injury showed that most often, middleborn children, brought up in a single-parent family environment, tend to such forms of behavior. The data are confirmed by the works of individual national and foreign authors [20, 40]. However, they contradict the works of C. Ernst and J. Angst, which indicate the absence of a unique connection between this problem and the birth order [41]. Apparently, agerelated features do not play a significant role in the formation of self-harming behavior.

In turn, the analysis of psychological characteristics allowed us to conclude that there is a significant relationship between selfconceptual components and a tendency to manifest self-destructive behaviors. Moreover, the range of personality characteristics associated with the peculiarities of the self-damaging behavior of girls is quite wide. For example, adolescents who show such features in behavior show obvious symptoms of negative attitude towards themselves and are more selfcentered. They tend to experience self-doubt and anxiety, possess emotional immaturity, demonstrativeness, the need to communicate with other people and, at the same time, increased sensitivity to criticism from others. Many indicators of the sovereignty of the psychological space of these adolescents are deprived, which causes them to feel estranged from reality, self-alienated and that their life is fragmented, which creates problems in the choice of objects of self-identification.

In turn, deprivation is the result and condition of reduced personal effectiveness, and is combined with various forms of maladaptation, leading to a weakening of personal responsibility, to the inability to make decisions [36]. It is characterized with emotional regulation problems, a tendency to self-accusations, which turn into autoaggressive actions in stressful situations. An interesting fact is that such features as emotional immaturity, impaired emotional self-regulation, demonstrativeness, self-centeredness, inadequate self- 
как эмоциональная незрелость, нарушение эмоциональной саморегуляции, демонстративность, эгоцентризм, неадекватность самооценки, тревожность и дезадаптивность, нестабильность в межличностном взаимодействии указывает не столько на специфику свойств личности, сколько на признаки незавершённости её созревания, то есть наличие психического инфантилизма, проявление которого обусловлено социально-психологическими факторами, неблагополучием в детско - родительских отношениях и школьной дезадаптацией, что подтверждает ряд социально - демографических данных.

Анализ структуры взаимосвязей элементов Яконцепции в основной группе, позволяет говорить, что подростки из этой группы зависимы от мнения окружающих, как и их негативная оценка собственной внешности, которая, в свою очередь, является определённым триггером, запускающим самоповреждающее поведение. В тоже время, аутоагрессия обостряет интерес к самому себе и позволяет демонстрировать себя другим. Что касается негативной оценки своей внешности и её влияния на аутоагрессию, схожие данные были получены J.J. Muehlenkamp с соавт. [23].

Необходимо отметить, что улучшение самоотношения и его отдельных элементов в основной группе лишь способствуют дезадаптивным проявлениям, а их усиление ведёт к снижению направленности на сотрудничество с другими людьми и усиливает готовность к проявлению открытой агрессии. Можно предположить, что последнее находит своё место в рамках детской поведенческой реакции оппозиции, к которой наиболее склонны демонстративные подростки, лишённые внимания со стороны значимых других, что подтверждается в работах отечественных авторов [42]. Судя по всему, существенную роль в формировании социальной дезадаптации, в появлении сниженной самооценки и нелюбви к себе играет высокий уровень эгоцентризма. В целом, сравнивая структуры взаимосвязей в основной и контрольной группах, следует сказать, что Я-концепция подростков с самоповреждающим поведением не выполняет своих функций и не способствует их адаптации к себе, а также социальной интеграции с другими людьми. В то время как в контрольной группе рост положительного отношения к себе снижает недовольство своим телом, риск проявления тревожности и неуверенности в себе, усиливает энергию и силу стремлений. При этом, именно Яконцепция может рассматриваться в качестве базовой основы для работы с подростками, проявляющими склонность к саморазрушающему поведению.

\section{Литература / References:}

1. Левковская О.Б., Шевченко Ю.С. Несуицидальное самоповреждающее поведение в подростковой среде: современ- esteem, anxiety and maladaptiveness, instability in interpersonal interaction indicate not so much the specificity of personality traits, but rather are the signs of its incomplete maturation, that is, the presence of mental infantilism, the manifestation of which comes as a result of socio-psychological factors, dysfunction in child-parent relations and school maladaptation, which is confirmed by a number of socio - demographic data.

An analysis of the structure of the interconnections of the elements of the self-concept in the main group allows us to say that adolescents from this group are dependent on the opinions of others, as well as their negative assessment of their appearance, which, in turn, triggers self-harming behavior. At the same time, auto-aggression exacerbates interest in oneself and allows to show oneself to others. Similar data on negative assessment of their appearance and its impact on auto-aggression were obtained by J.J. Muehlenkamp et al. [23].

It should be noted that improving selfattitude and its individual elements in the main group only contribute to manifestations of maladaption, and their strengthening leads to a decrease in focus on cooperation with other people and enhances readiness for manifestation of open aggression. It can be assumed that the latter finds its place in the framework of the children's behavioral opposition reaction, to which demonstrative adolescents are most inclined, deprived of attention from significant others, which is confirmed in other national works [42]. Apparently, a high level of selfcenteredness plays a significant role in the formation of social maladaptation, in the appearance of reduced self-esteem and selfdislike. In general, comparing the structures of relationships in the main and control groups, it should be said that the self-concept of adolescents with self-injury does not fulfill its functions and does not contribute to their adaptation to themselves, as well as social integration with other people. In the control group the growth of a positive attitude towards oneself reduces the dissatisfaction with one's body, the risk of anxiety and self-doubt, as well as increases the energy and strength of aspirations. Moreover, it is the self-concept that can be considered as the primary basis for working with adolescents who are prone to selfdestructive behavior. 
explanatory approaches. Mental health issues in children and adolescents. 2014; 14 (2): 124-132.] (In Russ)

2. Muehlenkamp J.J., Claes L., Havertape L., Plener P.L. International prevalence of adolescent non-suicidal self-injury and deliberate self-harm. Child Adolesc Psychiatry Ment Health. 2012; 6: 10. DOI: 10.1186/1753-2000-6-10.

3. Muehlenkamp J.J., Williams et al. Rates of Non-Suicidal SelfInjury in High School Students Across Five Years. Archives of suicide research: official journal of the International Academy for Suicide Research. 2009; 13 (4): 317-329.

4. Банников Г.С., Федунина Н.Ю., Павлова Т.С., Вихристюк О.В., Летова А.В., Баженова М.Д. Ведущие механизмы самоповреждающего поведения у подростков: по материалам мониторинга в образовательных организациях. Консультативная психология и психотерапия. 2016; 24 (3): 42-68. doi: 10.17759/cpp.20162403004 [Bannikov G.S., Fedunina N.Yu., Pavlova T.S., Vykhristyuk O.V., Letova A.V., Bazhenova M. D. Leading mechanisms of self-injuring behavior in adolescents: based on monitoring materials in educational organizations. Counseling psychology and psychotherapy. 2016; 24 (3): 42-68. doi: 10.17759/cpp.20162403004] (In Russ)

5. Ефимова А.Д. Связь любовной аддикции с иными вариантами аддиктивного поведения и саморазрушающим поведением. Девиантология. 2018; 2 (2): 18-25. [Efimova A.D. Relationship of love addiction with other addictive behaviors and self-destructive behavior. Deviant Behavior (Russia). 2018; 2 (2): 18-25.] (In Russ)

6. Ворошилин С.И. Влечения к модификации тела: акротомофилия, апотемнофилия и Интернет. Академический журнал $3 a$ падной Сибири. 2011; 3: 8-9. [Voroshilin S. I. Attraction to body modification: acrotomophilia, apotemnophilia and the Internet. Academic journal of Western Siberia. 2011; 3: 8-9.] (In Russ)

7. Польская Н.А., Якубовская Д.К. Влияние социальных сетей на самоповреждающее поведение у подростков. Консультативная психология и психотерапия. 2019; 27 (3): 156-174. doi: 10.17759/cpp.20192703010. [Polskaya N.A., Yakubovskaya D.K. Influence of social networks on self-harming behavior in adolescents. Counseling psychology and psychotherapy 2019; 27 (3): 156-174] (In Russ)

8. Favazza A. R. The coming of age of self-mutilation. The Journal of nervous and mental disease. 1998; 186 (5): 259-268.

9. Linehan M.M. Behavioral treatments of suicidal behaviors. Definitional obfuscation and treatment outcomes. Annals of the New York Academy of Sciences. 1997; 836 (1): 302-328.

10. Nock M.K., Joiner T.E., Gordon K.H., Lloyd-Richardson E., Prinstein M.J. Non-suicidal self-injury among adolescents: Diagnostic correlates and relation to suicide attempts. Psychiatry research. 2006; 144 (1): 65-72.

11. Nock M.K., Cha C.B. Dour H. Disorders of impulse-control and self-harm. In D.H. Barlow (Ed.), Oxford handbook of clinical psychology. New York, NY: Oxford University Press. 2011; 504529.

12. Ross S., Heath N. A study of the frequency of self-mutilation in a community sample of adolescents. Journal of Youth and Adolescence. 2002; 31 (1): 67-77.

13. Greydanus D.E., Apple R.W. The relationship between deliberate self-harm behavior, body dissatisfaction, and suicide in adolescents: Current concepts. J Multidiscip Healthc. 2011; 4: 183-189. doi: 10.2147/JMDH.S1 1569

14. Muehlenkamp J.J., Brausch A.M. Protective factors do not moderate risk for past-year suicide attempts conferred by recent NSSI. Journal of Affective Disorders. 2019; Feb 15; 245: 321 324. doi: 10.1016/j.jad.2018.11.013

15. Brent D.A. et al. Familial pathways to early-onset suicide attempt: risk for suicidal behavior in offspring of mooddisordered suicide attempters. Archives of general psychiatry. 2002; 59 (9): 801-807.

16. Nock M.K., Prinstein M.J., Sterba S.K. Revealing the form and function of self-injurious thoughts and behaviors: A real-time ecological assessment study among adolescents and young adults. Journal of abnormal psychology. 2009; 118 (4): 816.

17. Nock M.K., Kessler R.C. Prevalence of and risk factors for suicide attempts versus suicide gestures: Analysis of the National
Comorbidity Survey. Journal of Abnormal Psychology. 2006; 115 (3): 616-623.

18. Nixon M.K., Cloutier P.F., Aggarwal S. Affect regulation and addictive aspects of repetitive self-injury in hospitalized adolescents. Journal of the American Academy of Child \& Adolescent Psychiatry. 2002; 41 (11): 1333-1341.

19. Andover M.S., Morris B.W., Wren A., Bruzzese M.E. The cooccurrence of non-suicidal self-injury and attempted suicide among adolescents: distinguishing risk factors and psychosocial correlates. Child Adolesc Psychiatry Ment Health. 2012; Mar 30; 6: 11. doi: 10.1186/1753-2000-6-11

20. Hawton, K. Sex and suicide. Gender differences in suicidal behavior. British Journal of Psychiatry. 2000; 177: 484-485.

21. Попов Ю.В. Границы и типы саморазрушающего поведения у детей и подростков. Саморазрушающее поведение y подростков. 1991; 5: 9. [Popov Yu.V. Boundaries and types of self-destructive behavior in children and adolescents. Selfdestructive behavior in adolescents. 1991; 5: 9.] (In Russ)

22. Chapman A.L., Gratz K.L., Brown M.Z. Solving the puzzle of deliberate self-harm: The experiential avoidance model. Behaviour research and therapy. 2006; 44 (3): 371-394.

23. Muehlenkamp J.J., Bagge C.L., Tull M.T., Gratz K.L. Body regard as a moderator of the relation between emotion dysregulation and nonsuicidal self-injury. Suicide and LifeThreatening Behavior. 2013; 43 (5): 479-493. DOI: 10.1111/sltb.12032.

24. Favazza A.R., Conterio K. Female habitual self-mutilators. Acta Psychiatrica Scand. 1989; 79 (3): 283-289.

25. Klonsky E.D. The functions of deliberate self-injury: A review of the evidence. Clinical Psychology Review. 2007; 27: 226-239.

26. Фрейд 3. «Я» и «Оно» / Фрейд, 3. «Я» и «Оно». Труды разных лет. Т.1. Тбилиси, 1991; 351-392. [Freud, Z. "I" and " It " // Freud, Z. "I" and "It". Worksofdifferentyears. Vol. 1. Tbilisi. 1991; 351-392.] (In Russ)

27. Анзьё, Д. Я-кожа. Ижевск: ERGO, 2011; 302. [Anzia, D. I-skin. Izhevsk: ERGO, 2011; 302] (In Russ)

28. Мельникова М.Л. Телесная граница и агрессивность клинико-психологическое исследование. Ижевск. 2009; 180. [Melnikova M.L. Body boundary and aggressiveness clinical and psychological research. Izhevsk. 2009; 180] (In Russ)

29. Carroll J., Schaffer C., Spensley J., Abramowitz S.I., Family experiences of self-mutilating patients. The American journal of psychiatry. 1980; 137 (7): 852-853.

30. Whitlock B.K., Kaiser L., Maxwell H.S. Heritable bovine fetal abnormalities. Theriogenology. 2008; 70: 535-549.

31. Glassman L. H. et al. Child maltreatment, non-suicidal selfinjury, and the mediating role of self-criticism. Behaviour research and therapy. 2007; 45 (10): 2483-2490.

32. Hooley J.M., Ho D.T., Slater J., Lockshin A. Pain perception and nonsuicidal self-injury: a laboratory investigation. Personality Disorders: Theory, Research, and Treatment. 2010; 1 (3): 170179.

33. Столин В.В., Пантилеев С.Р. Практикум по психодиагностике: Психодиагностические материалы. М., 1988; 123-130. [Stolin V.V., Pantileev S.R. Practical Work on psychodiagnostics: Psychodiagnostic materials. M., 1988; 123130.] (In Russ)

34. Скугаревский О.А., Сивуха С.В. Образ собственного тела: разработка инструментария для оценки. Психологическийжурнал. 2006; 2: 40-48. [Skugarevsky O.A., Sivukha S.V. Image of your own body: development of tools for evaluation. Psychological journal. 2006; 2: 40-48.] (In Russ)

35. Муздыбаев К. Эгоизм личности. Психологический журнал. 2000; 21 (2): 27-39. [Muzdybaev K. Egoism of the person. Psychological journal. 2000; 21 (2): 27-39.] (In Russ)

36. Нартова-Бочавер С.К. Опросник «Суверенность психологического пространства» - новый метод диагностики личности. Психологический журнал. 2004; 25 (5): 77-89. [NartovaBochaver S.K. Questionnaire "Sovereignty of psychological space" - a new method of personality diagnostics. Psychological journal. 2004; 25 (5): 77-89.] (In Russ)

37. Курбатова Т.Н., Муляр О.И. Проективная методика исследования личности «Наnd-тест». Методическое руководство. 
СПб.: «ИМАТОН». 2001. 64 с. [Kurbatova T.N., Mulyar O.I Projective technique of personality research "Hand-test". Methodological guidance. SPb.: "Imaton". 2001. 64 p.] (In Russ)

38. Романова Е.С., Потемкина О.Ф. Графические методы в психологической диагностике. 1991; 256. [Romanova E.S., Potemkina O.F. Graphic methods in psychological diagnostics. 1991; 256.] (In Russ)

39. Фетискин Н.П., Козлов В.В., Мануйлов Г.М. Социальнопсихологическая диагностика развития личности и малых групп. 2002; 29-31. [Fetiskin N.P., Kozlov V.V., Manuilov G.M. Social and psychological diagnostics of personality development and small groups. 2002; 29-31.] (In Russ)

40. Польская Н.А. Феноменология и функции самоповреждающего поведения при нормативном и нарушенном психиче- ском развитии: Автореф. дис. ... докт. псих. наук. М. 2017; 432. [Polskaya N.A. Phenomenology and functions of selfharming behavior in normative and disturbed mental development: Authoref. dis. ... doct. crazy. sciences'. M. 2017; 432.] (In Russ)

41. Ernst, C., Angst, J. Birth order: Its influence on personality. Berlin and New York: Springer-Verlag. 1983; 59-70. https://doi.org/10.1007/978-3-642-68399-2_4

42. Польская Н.А., Власова Н.В. Аутодеструктивное поведение в подростковом и юношеском возрасте. Консультативная психология и психотерапия. 2015; 4: 176-190. [Polskaya N.A., Vlasova N.V. Auto-Destructive behavior in adolescence and youth. Counseling psychology and psychotherapy. 2015; 4: 176190.] (In Russ)

\title{
FEATURES OF SELF-CONCEPT OF FEMALE ADOLESCENTS WITH NON-SUICIDAL SELF-HARMING BEHAVIOR
}

\author{
S.V. Gorbatov, E.N. Arbuzova, \\ A.V. Shaboltas, V.V. Gorbacheva
}

Saint Petersburg state University, Saint Petersburg, Russia; s.gorbatov@bk.ru

\section{Abstract:}

Non-suicidal self-injury has become widespread among young people in many developed countries of the world, and therefore is a serious medical and social problem that requires comprehensive research to develop effective measures of assistance and prevention. The aim of the study: to study the characteristics and determinants of the selfdamaging behavior of teenage girls based on the analysis of various elements of self-concept. Sample characteristics and methods. 76 girls aged 15 to 17 were examined, 37 of whom had various manifestations of self-destructive behavior (the main group), and 39 were healthy (control group). As self-destructive were considered forms that suggested self-injury or physical harm to oneself in the absence of conscious suicidal intentions. In order to highlight significant differences between the groups, a level analysis of a number of basic psychological characteristics was carried out. Statistical data processing was performed using the SPSS-21 software package. Results. It was found that in the structure of personality traits of adolescents with self-injury, the largest share is made up of factors associated with self-concept. In particular, they have more pronounced indicators of self-accusation (83.68 in the main group and 47.18 in the control), dissatisfaction with their body (7.83 and 6.08), egocentrism (24.22 and 12.05). Self-attitude (24.84 and 78.35), self-esteem (19.27 and 70.9) and self-sympathy (33.35 and 61.54) are less pronounced, while the overall level of maladaptation (1.68 and 1.08) is increased. According to the results of the study, it was concluded that the self-concept of adolescents characterized by non-suicidal self-injury is dysfunctional. It does not perform functions that promote psychological adaptation and social integration of adolescents, which can, in general, be considered as a factor of increased suicidal risk.

Keywords: self-harming behavior, suicide, self-concept, teenager

Вкмад авторов:

С.В. Горбатов: формулировка концепции и структуры исследования, написание текста рукописи;

E.H. Арбузова: $\quad$ написание текста рукописи, анализ данных митературы, интерпретация данных;

А.В. Шаболтас: анализ результатов исследования, написание текста рукописи;

В.В. Горбачева: получение данных для анализа, статистическая обработка.

Authors' contributions:

S.V. Gorbatov: formulation of the concept and structure of the study, article writing;

E.N. Arbuzova: article writing, reviewing relevant publications, interpretation of data;

A.V. Shaboltas: analysis of the obtained data, article writing;

V.V. Gorbacheva: empirical research, statistical data processing.

Финансирование: Данное исследование не имемо финансовой поддержки.

Financing: The study was performed without external funding.

Конфмикт интересов: Авторы заявцяют об отсутствии конфиикта интересов.

Conflict of interest: The authors declare no conflict of interest.

Статья поступима / Article received: 12.09.2019. Принята к публикации / Accepted for publication: 12.02.2020.

Для цитирования: Горбатов С.В., Арбузова Е.Н., Шаболтас А.В., Горбачева В.В. Особенности Я-концепции девочек подростков с несуицидальным самоповреждающим поведением. Суицидология. 2020; 11 (1): 53-69. doi.org/10.32878/suiciderus.20-11-01(38)-53-69

For citation: $\quad$ Gorbatov S.V., Arbuzova E.N., Shaboltas A.V., Gorbacheva V.V. Features of Self-concept of female adolescents with non-suicidal self-harming behavior. Suicidology. 2020; 11 (1): 53-69. (In Russ) doi.org/10.32878/suiciderus.20-11-01(38)-53-69 